August 2001 - NREL/CP-710-30554

\title{
Financing Distributed Generation
}

\section{Preprint}

\author{
Andy Walker, PhD, PE
}

To be presented at the Association of Energy Engineers Annual Conference

Atlanta, Georgia

October 24-26, 2001
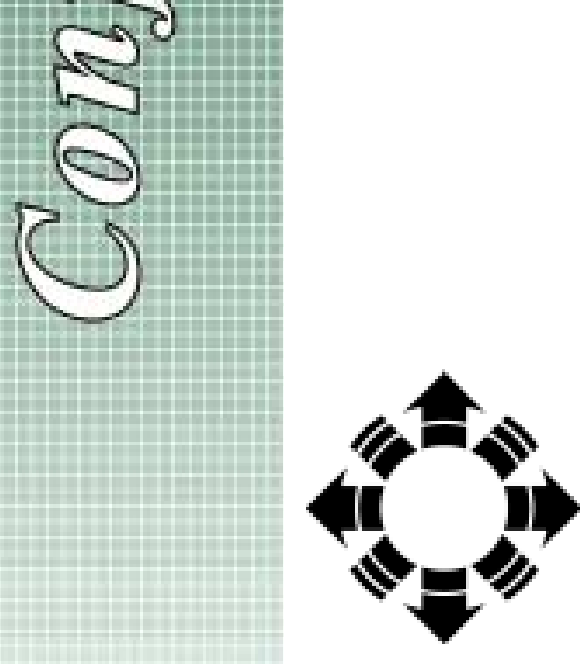

\section{National Renewable Energy Laboratory}

1617 Cole Boulevard

Golden, Colorado 80401-3393

NREL is a U.S. Department of Energy Laboratory

Operated by Midwest Research Institute $\bullet$ Battelle $\bullet$ Bechtel

Contract No. DE-AC36-99-G010337 


\section{NOTICE}

The submitted manuscript has been offered by an employee of the Midwest Research Institute (MRI), a contractor of the US Government under Contract No. DE-AC36-99G010337. Accordingly, the US Government and MRI retain a nonexclusive royalty-free license to publish or reproduce the published form of this contribution, or allow others to do so, for US Government purposes.

This report was prepared as an account of work sponsored by an agency of the United States government. Neither the United States government nor any agency thereof, nor any of their employees, makes any warranty, express or implied, or assumes any legal liability or responsibility for the accuracy, completeness, or usefulness of any information, apparatus, product, or process disclosed, or represents that its use would not infringe privately owned rights. Reference herein to any specific commercial product, process, or service by trade name, trademark, manufacturer, or otherwise does not necessarily constitute or imply its endorsement, recommendation, or favoring by the United States government or any agency thereof. The views and opinions of authors expressed herein do not necessarily state or reflect those of the United States government or any agency thereof.

Available electronically at http://www.doe.gov/bridge

Available for a processing fee to U.S. Department of Energy and its contractors, in paper, from:

U.S. Department of Energy

Office of Scientific and Technical Information

P.O. Box 62

Oak Ridge, TN 37831-0062

phone: 865.576 .8401

fax: 865.576.5728

email: reports@adonis.osti.gov

Available for sale to the public, in paper, from:

U.S. Department of Commerce

National Technical Information Service

5285 Port Royal Road

Springfield, VA 22161

phone: 800.553 .6847

fax: 703.605.6900

email: orders@ntis.fedworld.gov

online ordering: http://www.ntis.gov/ordering.htm

Printed on paper containing at least $50 \%$ wastepaper, including $20 \%$ postconsumer waste 


\title{
FINANCING DISTRIBUTED GENERATION
}

\author{
Andy Walker, PhD, PE \\ National Renewable Energy Laboratory \\ 1617 Cole Boulevard \\ Golden, CO 80401-3393 \\ andy walker@nrel.gov
}

\begin{abstract}
This paper introduces the engineer who is undertaking distributed generation projects to a wide range of financing options. Distributed generation systems (such as internal combustion engines, small gas turbines, fuel cells and photovoltaics) all require an initial investment, which is recovered over time through revenues or savings. An understanding of the cost of capital and financing structures helps the engineer develop realistic expectations and not be offended by the common requirements of financing organizations. This paper discusses several mechanisms for financing distributed generation projects: appropriations; debt (commercial bank loan); mortgage; home equity loan; limited partnership; vendor financing; general obligation bond; revenue bond; lease; Energy Savings Performance Contract; utility programs; chauffage (end-use purchase); and grants. The paper also discusses financial strategies for businesses focusing on distributed generation: venture capital; informal investors ("business angels"); bank and debt financing; and the stock market.
\end{abstract}

\section{ACKNOWLEDGEMENT}

This paper was prepared in support of the U.S. Department of Energy (DOE) Federal Energy Management Program (FEMP), Beth Shearer, Director. FEMP promotes the financing of cogeneration as an energy efficiency measure by providing goevernment agencies with technical, procurement, and financing assistance.

\section{INTRODUCTION}

Distributed generation refers to the use of energy systems such as internal combustion engines, gas turbines, fuel cells, wind power, and photovoltaics to generate electric power on site. Utilizing waste heat in a cogeneration application maximizes the benefits of distributed generation. Distributed generation resources are characterized by high initial costs and benefits that accrue over time. Financing converts the future stream of revenues or savings into the required initial investment. And technologies with the lowest initial costs may have higher operating costs. Whether the higher cost of fuel cells or photovoltaics is justified by fuel cost savings depends largely on the terms of the financing arrangement. Strategies to extend the term of financing and reduce the interest rate will speed the implementation of these cleaner, more efficient technologies.

Alternatives for financing either public or private distributed generation projects include:

- Appropriations (using your agency's or your organization's own money);

- Debt (commercial bank loan);

- Mortgage and home equity loan;

- Limited partnership;

- Vendor financing;

- General obligation bond;

- Revenue bond;

- Lease;

- Energy Savings Performance Contract;

- Utility programs;

- Chauffage (end-use purchase); and

- Grants. 
Strategies for financing a business related to distributed generation include the following alternatives:

- Venture Capital;

- Informal Investors, "Angels," and Seed Investors;

- Bank and Debt Financing; and

- The Stock Market.

\section{AN EXAMPLE OF DISTRIBUTED GENERATION ECONOMICS}

Key financing concepts are introduced in a simple example, which concerns financing the initial cost of a distributed generation system. Operating and overhaul expenses are covered by revenue derived through operating the plant. Initial costs vary widely, depending on the technology and auxiliary equipment such as heat recovery, emissions controls, and fuel delivery systems. The cost estimates in Table 1 are by the author for a $1 \mathrm{MW}$ plant in California. Costs include engineering, hardware, installation, air pollution control, utility interconnect, and heat recovery equipment, including absorption cooler. These per-kilowatt costs cannot be compared directly, since the natural gas fueled engines, turbines, and fuel cells generate rated power 8,322 hours/year $(95 \%$ availability $)$ but photovoltaics does so only 1,800 hours/year and the wind turbine does so only 876 hours/year in this San Francisco example [20].

Table 1. Example of Initial Costs of Distributed Generation Options

\begin{tabular}{|l|l|}
\hline Technology & Initial Cost $(\$ / \mathrm{kW})$ \\
\hline $\begin{array}{l}\text { Internal Combustion } \\
\text { Engine }\end{array}$ & $\$ 1,400$ \\
\hline Small Gas Turbine & $\$ 2,000$ \\
\hline Fuel Cell & $\$ 5,300$ \\
\hline Photovoltaics & $\$ 8,000$ \\
\hline Wind & $\$ 1,250$ \\
\hline
\end{tabular}

After the system is installed, savings in the utility bill or revenue from the sale of electricity generate income, while fuel costs and operation and maintenance costs are ongoing expenses. The difference between operating revenue (or savings) and operating costs represents the rate at which the initial investment is being returned. In this example, the electricity costs are taken at $\$ 0.0954 / \mathrm{kWh}$ and gas costs at $\$ 4.88 /$ million Btu of natural gas [11]. A $\$ 30 / \mathrm{kW} /$ year utility standby charge is subtracted from the revenue streams.
Table 2. Example of Annual Cash Flows of Distributed Generation Options

\begin{tabular}{|l|l|l|l|}
\hline Technology & $\begin{array}{l}\text { Electricity } \\
\text { Savings } \\
(\$ / \mathrm{kW} / \mathrm{yr})\end{array}$ & $\begin{array}{l}\text { Fuel } \\
\text { Costs } \\
(\$ / \mathrm{kW} / \mathrm{yr})\end{array}$ & $\begin{array}{l}\text { O\&M } \\
\text { Costs } \\
(\$ / \mathrm{kW} / \mathrm{yr})\end{array}$ \\
\hline $\begin{array}{l}\text { Internal Comb } \\
\text { Engine }\end{array}$ & $\$ 812$ & $\$ 370$ & $\$ 95$ \\
\hline $\begin{array}{l}\text { Small Gas } \\
\text { Turbine }\end{array}$ & $\$ 793$ & $\$ 462$ & $\$ 66$ \\
\hline Fuel Cell & $\$ 751$ & $\$ 292$ & $\$ 125$ \\
\hline Photovoltaics & $\$ 171$ & $\$ 0$ & $\$ 20$ \\
\hline Wind & $\$ 71$ & $\$ 0$ & $\$ 15$ \\
\hline
\end{tabular}

With a cost of $\$ 1,400 / \mathrm{kW}$ and annual net cash flow of $\$ 317 / \mathrm{kW} /$ year, the internal combustion engine option would have a simple payback period of 4.4 years. Say we wish to borrow the $\$ 1,400 / \mathrm{kW}$ and pay it back at a rate that does not exceed our annual net cash flow of $\$ 317 / \mathrm{kW}$. Table 3 shows the required term to amortize the $\$ 1,400 / \mathrm{kW}$ investment for the indicated interest rate. It is seen that the required term of the financing increases with the interest rate. Increasing the interest rate above $23 \%$ in this example makes the term go to infinity, and financing is not viable because the payment does not cover the interest. A negative amortization, where the principal balance increases, is available but not recommended.

Table 3. Term Required to Amortize Initial Investment with Payments (Initial investment of $\$ 1400$, and payments of $\$ 317 / \mathrm{yr}$ )

\begin{tabular}{|l|l|}
\hline $\begin{array}{l}\text { Interest Rate } \\
(\% / y r)\end{array}$ & $\begin{array}{l}\text { Term } \\
(\mathrm{yrs})\end{array}$ \\
\hline $20 \%$ & 11.8 \\
\hline $15 \%$ & 7.8 \\
\hline $10 \%$ & 6.1 \\
\hline $5 \%$ & 5.1 \\
\hline
\end{tabular}

FINANCING TERM AND INTEREST RATE The term is the time period over which the principal is scheduled to be paid down through periodic payment, and is often less than the project lifetime. The interest rate is the factor multiplied by the remaining principal amount to determine the annual cost of financing. The interest rate is often expressed as a published index plus a lender spread, plus a hedge, plus a prepayment adder.

The index is a published reference interest rate that may be the prime rate (the rate at which banks lend money to each other or to their best 
customers), the LIBOR (London Interbank Offered Rate) or the rate associated with Treasury Bills of similar term (referenced by Federal reviewers). A published rate called the "swap rate" is increasing in popularity as an index. The swap rate is the current fixed rate which traders would exchange for a variable rate.

To the index, a financer would add a lender spread. The lender spread covers legal and administrative costs, and usually adds $0.1 \%$ to $0.3 \%$ to the index.

A hedge would be paid to lock in a quoted interest rate for a specified time period. This hedge against future rates going up typically adds $0.4 \%$ to the interest rate. The hedge is highly dependent upon interest rate volatility.

If you want to be able to terminate the contract early by paying it off, the financing organization (financer) will add a prepayment adder to cover the possibility of interest going down and also to cover the administrative transaction costs. The option to prepay entails that you pay these costs whether you prepay or not.

An adjustable interest rate changes periodically according to a selected index. The initial interest rate is lower than that of fixed interest rates, but monthly payments can go up or down as the rate is adjusted. Typical adjustment intervals are 6 months and one year.

Monthly payments depend on the dollar amount financed, the term, and the interest rate. A longer term will reduce payments, but at the expense of paying interest charges over a longer time period. Strategies to consider include these:

- Maintain positive cash flow. This strategy is required for Federal energy savings performance contracts or for Revenue Bonds. Financing is structured such that payments to the financer do not exceed revenues or savings from the project.

- Minimize life-cycle cost. If your minimum attractive rate of return is less than the interest rate (often the case), maximizing the payments and minimizing the term of the financing will minimize project life-cycle cost.

\section{FACTORS AFFECTING INTEREST RATES}

Interest rates depend on the perceived risk of a project and recourse or non-recourse financing. In recourse financing, the borrower is required to make payments to the lender, whether or not the project is performing as expected. In nonrecourse financing, the supplier of the distributed generation system gets paid and walks away, and the lender expects repayment from the end-user from the project performance. In non-recourse financing the interest rate will be higher to cover the lender's increased risk, and the lender's decision to finance a project is based on the creditworthiness of the end-user, rather than that of the supplier.

\section{RECOMMENDATIONS TO REDUCE THE INTEREST RATE}

- Consult with financer throughout development of the distributed generation contract to ensure that contract requirements do not cause financing problems [9].

- Mitigate the risk of project nonperformance. Include a "protection of lienholder interest" (financer has right to cure problems) or take performance risk off the financer (in non-recourse financing). While is it tempting to saddle the financer with performance risk, the result is a higher cost of capital.

- Include a fixed termination schedule in the contract so the costs corresponding to termination at any time are clear [9].

- Fix settlement and acceptance dates. Uncertainty or slippage in these dates results in high-cost financing [9].

- Ensure fixed rather than fluctuating payments. This may require an energy service company to collect variable revenues and make fixed payments.

- Make payments on time.

- Bundle small projects together to result in a larger package.

- Be ready to act when negotiating. The best rates are obtained without a hedge, and if the negotiator is ready to close the deal on financing. Locking in rates for a long period of time results in an expensive hedge cost [9]. 
- Escrow or hedge? Evaluate whether it is cheaper to structure the financing in stages with a hedge (to secure the future interest rates), or to finance the entire project, keeping the money in an interest-bearing account until used [9].

- Make your deal more like standard, commercial securities. Anything unusual to the financer will delay or impede financing and result in a higher cost. Ask financers for an example structure before structuring the contract between the distributed generation supplier and customer [9].

\section{TAX EFFECTS}

Tax effects include income tax, property tax, and the depreciation in the value of the distributed generation equipment. Tax effects depend on the status and tax liability of the parties, on the financing mechanism utilized, and even on the technology employed. For example, solar distributed generation projects would currently enjoy a 10\% Federal business investment tax credit.

\begin{abstract}
APPROPRIATIONS
Appropriations are your organization's own funds used to purchase a system outright. A key question is: Do you have the cash? Funding requests for a distributed generation plant may compete with mission-critical needs for money. The cost-effectiveness of a distributed generation project would be evaluated using your organization's "Minimum Attractive Rate of Return" (MARR). For large organizations, such as the Federal government, appropriations often represent the lowest "cost of money." For example, the Federal government MARR is that of a Treasury bill rate of comparable term, currently $3.3 \%$ real (net of general price inflation) or $6.1 \%$ nominal (including inflation) [1]. The minimum attractive rate of return may be much higher for small businesses struggling to make payroll. In a survey of Chief Financial Officers, $90 \%$ expected rates of return greater than $10 \%$, and the median expected rate of return was $18 \%$ [10]. When considering appropriations versus financing by a second party, this minimum attractive rate of return could be compared to the offered interest rate.
\end{abstract}

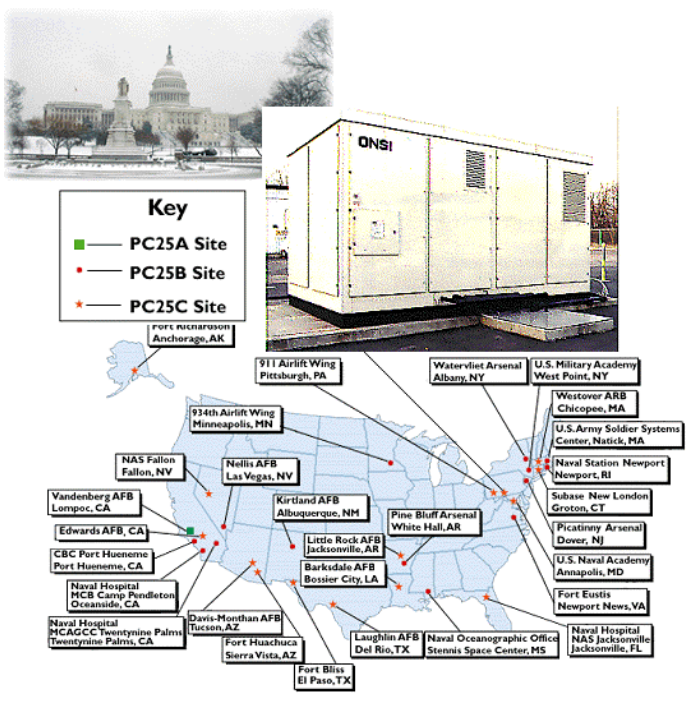

Distributed Generation (DG) Financing

Example 1: Appropriations. In the Dept. of Defense Fuel Cell Demonstration Program, Congress appropriated \$18 million in Fiscal Year 1993 and \$18.75 million in FY 1994. Over 30 IFC ONSI 200-kW Fuel Cells were installed and monitored at Federal facilities. The in situ performance is reported at http:// dodfuelcell.com/ site performance.php3 [13].

\section{DEBT (COMMERCIAL BANK LOAN)}

Availability of a commercial loan from your bank depends on your credit history and financial statements. You must be able to demonstrate the required cash flow to pay the loan back. Even then, you must provide collateral that the bank will receive if you don't pay the loan back. Debt is characterized by fixed payments over the loan term (principal plus interest) regardless of the actual project performance. Establishing a "line of credit" with your bank avoids re-application fees if you expect numerous transactions. A "Catch 22" with debt is that if you qualify for a bank loan, you don't need one. For example, a company with $\$ 1,000,000$ net worth and good income might qualify for a $\$ 200,000$ loan [7]. However, a bank loan would allow you to keep your cash for emergencies. The Small Business Administration can guarantee loans up to $\$ 750,000$ for solar thermal, photovoltaics, energy efficiency, biofuels, industrial cogeneration, hydroelectric power, and wind energy [2]. While this guarantee might not reduce your interest rate, it might affect your ability to secure financing. 


\section{HOME MORTGAGE OR HOME EQUITY LOAN}

Home mortgages have several advantages as a way of financing small-scale distributed generation:

- Interest rates are kept low by the operation of Federal Loan Associations, which implement Federal policy;

- Interest rates on home mortgages are tax deductible, resulting in a lower effective project cost.

- Terms of 15 to 30 years are much longer than available through other types of financing. Most financers prefer a term of less than 10 years.

A disadvantage is that the cost of the distributed generation system may add to appraised value of the house, increasing the mil levy property taxes.

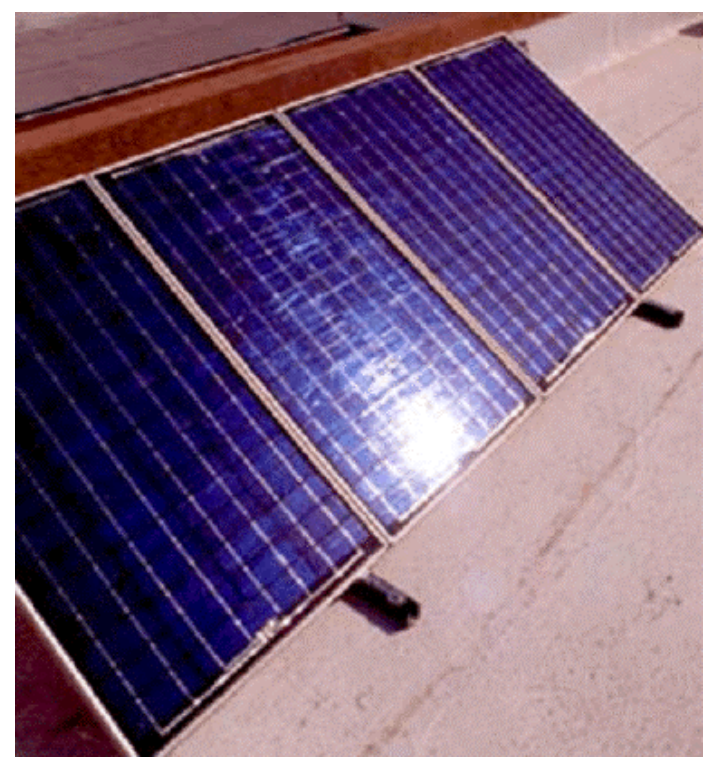

DG Financing Example 2: Home Mortgage. A 960-watt photovoltaic array was installed on Dorothy and Jerry's new home in Tucson, Ariz. The PV cost was $\$ 12,000$ out of a $\$ 280,000$ home loan. The loan had a 30-year term and a $7.8 \%$ interest rate. The $\$ 87 /$ month payments for $\mathrm{PV}$ are fixed, while the owners expect the cost of utility power to escalate. Dorothy likes the utility savings, tax benefits, reliability, silence, and lack of pollution [14].
All of the Federal Home Loan Associations have similar programs that promote distributed generation as an energy efficiency or renewable energy measure [2]:

\section{- Federal National Mortgage Association} (Fannie Mae):

-Mortgage up to $\$ 240,000$, market interest rates, allow $2 \%$ increase in debt-to-income ratio for energy efficient home, secured, 30-year term.

-Residential Energy Efficiency Improvement Loans up to $\$ 15,000$ (or up to $10 \%$ of base loan), below-market interest rates, unsecured, 10-year term.

- Federal Home Mortgage Loan Corp. (Freddie Mac):

$-\mathrm{Up}$ to $\$ 240,000$, market interest rates or variable prime plus $2 \%$. Up to $10 \%$ above base loan amount with Energy Efficient Mortgage.

- U.S. Dept of Housing and Urban Development (HUD):

$-\mathrm{Up}$ to $10 \%$ above base loan amount with Energy-Efficient Mortgage.

- U.S. Department of Veterans Affairs (VA): -For veterans. Up to $\$ 230,000$, up to $10 \%$ above base loan amount with Energy-Efficient Mortgage.

\section{GENERAL and LIMITED PARTNERSHIP}

In a partnership, a general partner is a partner whose liability is not limited. All partners in an ordinary partnership are general partners. A limited partner is passive, and liability of the limited partner is limited to the amount invested. A limited partnership must have at least one general partner whose liability extends beyond monetary investment in the project.

Members of a partnership would pool their money in order to invest in a project. There would be no guaranteed rate of return, since the rate of return would depend on the economic performance of the actual project. Often called "friends and family" financing, partnerships are a mechanism to raise funds for small projects. Partnerships lend themselves to strategic alliances. For example, a natural gas Local Distribution Company might partner with supplier of fuel cells. Joint ventures are like partnerships that dissolve when the project is complete. 


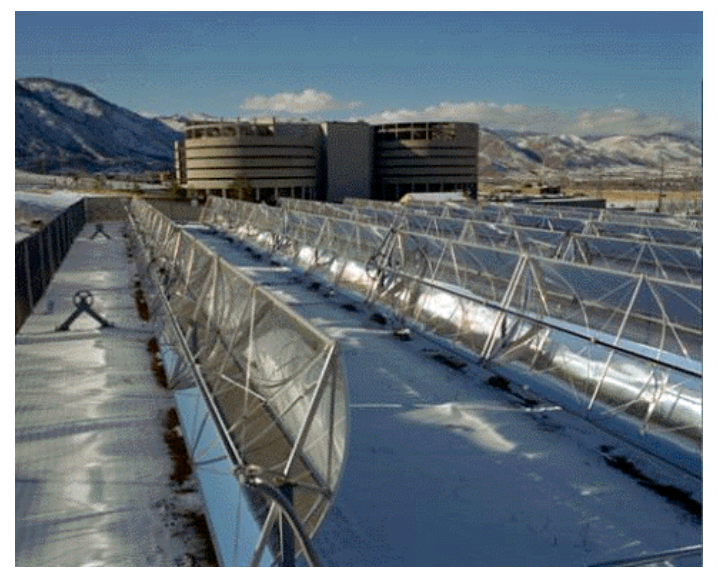

DG Financing Example 3: Limited Partnership. The Jefferson County Jail has a 7,200-ft ${ }^{2}$ solar trough system. The system installed cost was $\$ 160,000$, including 15 years of O\&M. Industrial Solar Technology Inc. raised capital through the limited partnership. Heat is sold to the prison at $90 \%$ of current natural gas cost. Investors are paid back from revenue, but receive not less than $\$ 8000 / y e a r[17]$.

\section{VENDOR FINANCING}

Singer Co. might be the first example of a manufacturer offering financing as marketing, enabling poor but industrious seamstresses to buy sewing machines "in installments." A third party such as a bank often is the actual source of financing. Vendor financing is very common among energy technologies, and offering easy, low-cost financing is a very effective way for suppliers to stimulate markets. Credit can even be applied for on some vendor's websites. Vendor financing may be most suitable for small projects $(\$ 25,000$ to $\$ 400,000)$, but large companies also finance large projects. Vendors advertise low interest rates if the vendor profits from the sale. Avoid vendor financing involving credit-card-type interest rates. It is often effective for large facilities to establish "lines of credit" with one or more vendors.
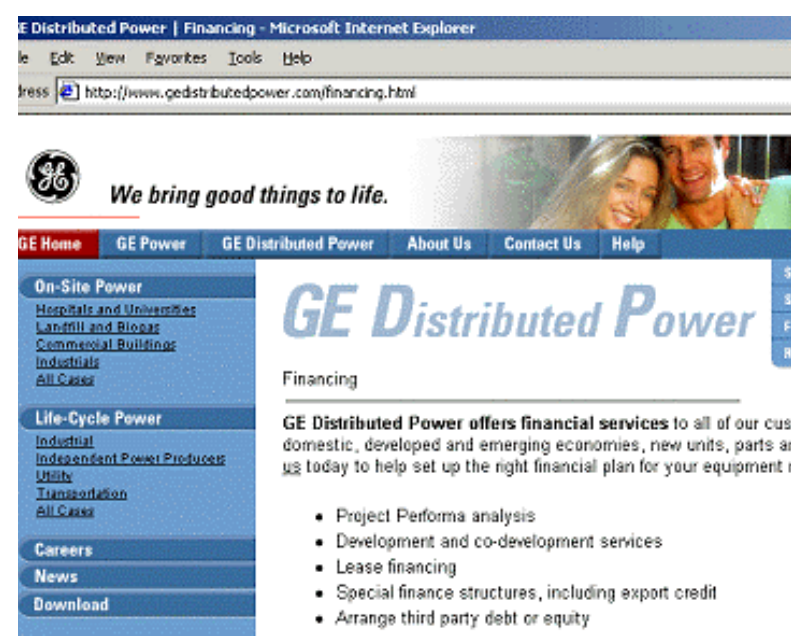

DG Financing Example 4: Vendor Financing. General Electric Distributed Power offers financing along with hardware and other project services. GE has financed energy projects from $300 \mathrm{~kW}$ to $15 \mathrm{MW}$. A wide variety of financing mechanisms have been used, including Lease; Debt; Equity; Preferred Stock; Partnerships; and $3^{\text {rd }}$-Party Financing. Projects totalling $\$ 19$ billion and $15 \mathrm{GW}$ have been financed since 1982 .

\section{BONDS}

A distributed generation project would have payment bonds to guarantee that suppliers get paid and completion bonds to mitigate the risk of project delays. But this discussion is about investment bonds: interest-bearing certificates sold by corporations and governments (states, counties, municipalities, school districts, and statutory authorities) to raise money for projects. General obligation bonds are issued by state or local governments and paid out of a general fund. Bonds are secured by assets or by the "good faith and credit" (taxing power) of the issuer. The process of issuing general obligation bonds is long and complicated, and often resisted by taxpayers.

Revenue bonds, on the other hand, are paid back by electric rates charged to customers and do not require the imposition of taxes. These are commonly issued by public utilities, and regional power supply systems are the largest borrowers in tax-exempt bond markets [21]. The approval process for revenue bonds is usually limited to the utility board or to the city council, making revenue bonds much easier and quicker to issue than general obligation bonds. Bond interest 
rates are often low, but depend on the bond's rating and on market conditions.

\section{LEASE}

Leasing of distributed generation resources is very common in the private sector. A distributed generation business strategy might be to bundle into the lease payments services such as maintenance, insurance, and property taxes. A lease is designated as either a capital equipment lease or an operating lease for financial reporting purposes. A capital equipment lease appears on the balance sheet as debt for a purchase and is characterized by any of the following:

- There is transfer of ownership at the end of the lease.

- A dollar buyout clause specifies the terms of future exchange of ownership.

- The lease term is $75 \%$ of equipment lifetime or longer.

- The net present value of lease payments adds up to $90 \%$ of the equipment's value.

An operating lease appears as an operating expense, rather than as a debt, on the balance sheet. The lessor would often have a large residual position in the equipment, so that the lessor would retrieve or sell the equipment at the end of the lease period.

Municipal leases are tax-exempt under Section $103 \mathrm{c}$ of the IRS Code (1986) and offer belowmarket rates similar to bonds.

Often, the lessor will borrow the project capital from a third party, in a leveraged lease. The lessor then assigns the future lease payment stream to the lender. The lessor puts up a minimal amount of its own equity, and is generally entitled to the tax benefits of asset depreciation.

\section{ENERGY SAVINGS PERFORMANCE CONTRACTS}

Energy Savings Performance Contracts (ESPCs) are contracts in which an energy service company (ESCO) finances a project in exchange for a share of the energy cost savings. This is suitable for customers that need the assurance of the "P" in ESPC: Performance. Many customers might shy away from new technologies such as solar cells or fuel cells because they are afraid they won't work. ESPC mitigates this risk by guaranteeing performance and often leaving O\&M in the hands of specialists. The legislation authorizing ESPC for Federal agencies requires that: payments to the ESCO be less than energy cost savings, the term be less than 25 years, and measurement and verification of annual energy cost savings be performed. The risk of project performance usually falls on the ESCO. Interest rates for ESPCs are typically the prime rate plus $1.25 \%$ to $1.5 \%$, depending on recourse or nonrecourse and perceived risk. In practice, the contract term is often less than 15 years.

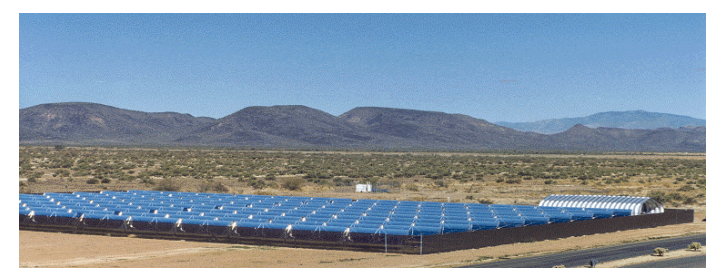

DG Financing Example 5: Energy Savings Performance Contracting. Phoenix Federal Correctional Institution signed an ESPC with Industrial Solar Technology Inc. (IST) for a $17,040-\mathrm{ft}^{2}$ solar water heating system. The installed cost was $\$ \mathbf{6 5 0 , 0 0 0}$. The system delivered $1,161,803 \mathrm{kWh}$ and saved $\$ 77,805$ in 1999. Payments to IST at $90 \%$ of electric rate were $\$ 70,025$ in 1999; the term is 20 years.

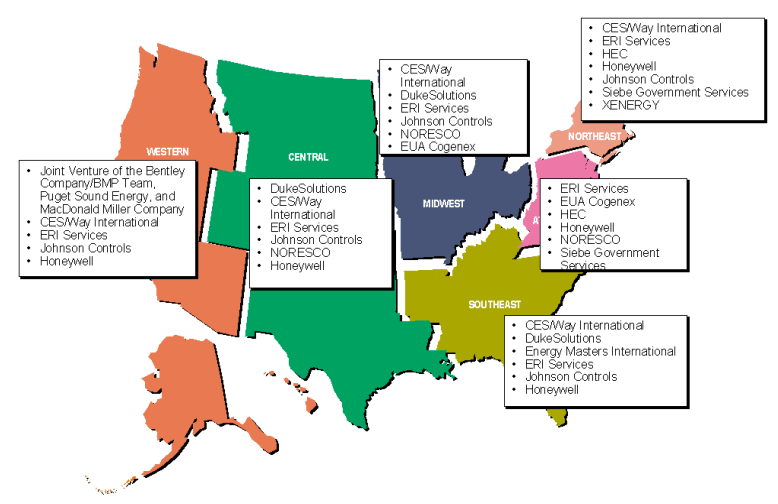

Figure 1. Map of U.S. Department of Energy Regions and FEMP Super ESPC Contractors

In order to streamline the ESPC process for Federal agencies, DOE FEMP has signed indefinite quantity contracts with ESCOs on a regional basis. FEMP has contracts with several ESCOs, as indicated on the map of Figure 1. These contracts, dubbed "Super ESPCs," are available for any Federal agency to secure financing for any distributed generation technology. Costs to use the contracts vary from $\$ 10,000$ to $\$ 50,000$, depending on the technical 
assistance required from FEMP, and they are suitable for comprehensive projects that include efficiency measures as well as cogeneration (for on-site energy use only).

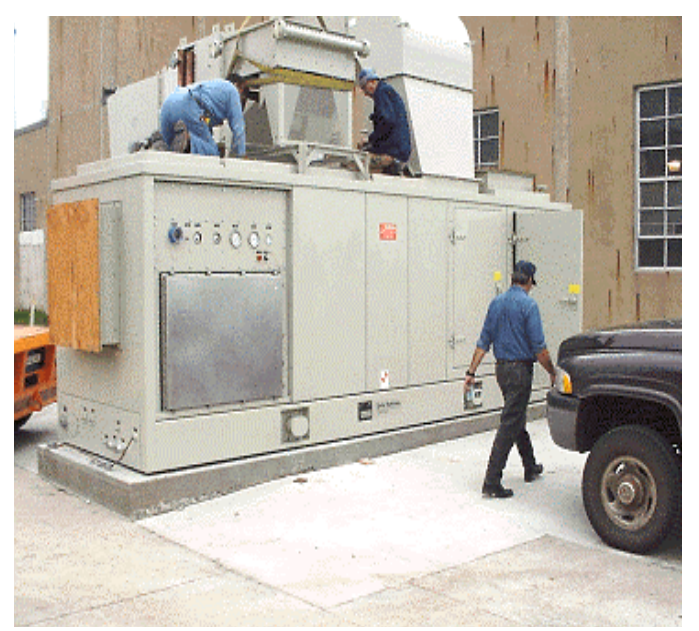

DG Financing Example 6: SUPER ESPC. Delivery order under the Central Regional Super ESPC was issued to Johnson Controls from the U.S. Department of Agriculture National Animal Disease Center, Ames, Iowa, on December 16, 1999. The delivery order includes a 1.2-MW solar gas turbine with cogeneration heat recovery. Annual savings of $\$ 378,000 /$ year are attributed to the distributed generation. Investment cost was $\$ 6.3$ million (includes other measures). The term is 18 years and the interest rate is $\mathbf{7 . 6 7 \%}$ (index plus $2.38 \%$ ).

\section{UTILITY FINANCING}

Utilities can consider distributed generation as a substitute for wire-based revenue or as a strategy to cut cost and enhance wire-based revenue. When considered a substitute for wire-based revenue, a utility company might offer distributed generation services through an unregulated energy services business. The utility would arrange third-party, non-recourse financing for the project. Why would utilities want to compete with their own electric power supply business? In the words of David Freeman of the Sacramento Municipal Utility District, "If they don't, and rates go up sharply, people are going to buy their own solar panels and pull the plug on the utilities" [3].
The alternative perspective for utilities would be to use distributed generation systems to reduce the cost of serving new or remote customers and thus enhance wire-based revenue. Utilities could avoid the cost of transmission upgrades and the problems of siting a new central plant. In this case, utilities could use the same shareholder financing, bonds, or operating budgets that they use to serve customers with centralized generation systems.

Utilities can implement several different types of programs to finance distributed generation systems. Perhaps the simplest is to finance a distributed generation project through contracts and ordering agreements. These are the same mechanisms that a customer would use for the procurement of basic electric power.

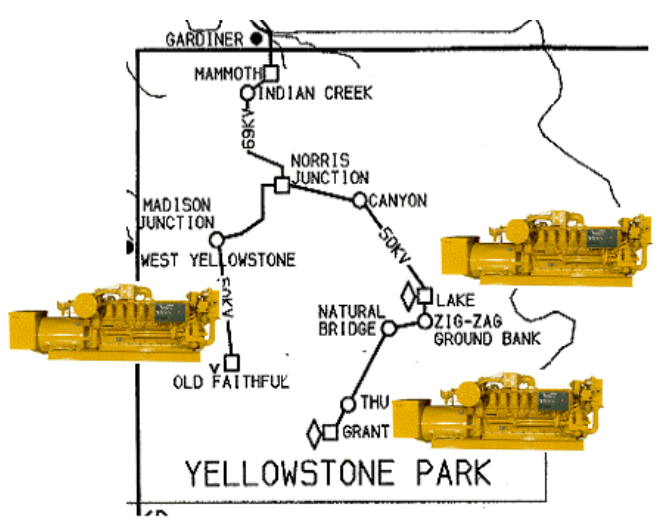

DG Financing Example 7: Utility Contract. Diesel Generators distributed in Yellowstone National Park include 2.75 MW at Lake, 1.0 MW at Old Faithful, and 1.6 MW at Grant. Capital investment was $\$ 12.5$ million. The contract term is 10 years. Rate of return for Montana Power Company is $8.9 \%$. Cost paid by the park is $3.9 \mathrm{c} / \mathrm{kWh}$ for energy plus $10.1 \mathrm{c} / \mathrm{kWh}$ for financing costs and $O \& M$ $(14 \mathrm{c} / \mathrm{kWh}$ total cost of power).

Utilities might offer incentives for distributed generation projects as part of Demand Side Management (DSM) bidding programs. The utility might offer technical assistance, low-cost financing, or rebates to encourage distributed generation as an integrated resource. For example, Hawaiian utilities offer $\$ 800$ rebates for residential solar water heaters. 
A utility might also offer distributed generation services though tariffs approved by state public utility commissions. Payments and terms might be fixed in the approved tariff, and interest rates might be comparable to shareholder returns (usually higher than other types of financing).

FEMP offers policy guidance, training, sample agreements, and technical assistance to support Federal agencies in negotiating Utility Energy Services Contracts (UESCs). FEMP also coordinates the Utility Partnership Working Group to address utility contracting issues and the effects of utility deregulation.

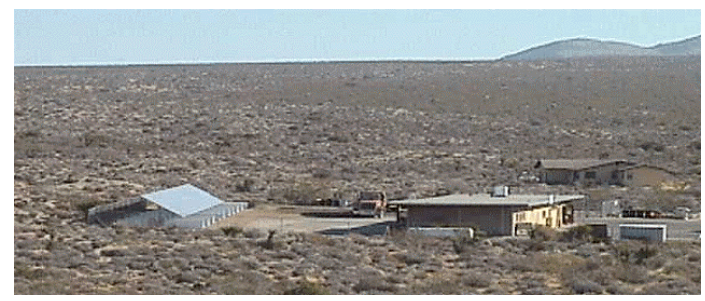

DG Financing Example 8: Utility Tariff. A $20.5-\mathrm{kW}$ photovoltaic array is at Joshua Tree National Park. The $\$ 273,000$ cost was financed by Southern California Edison. Monthly payments of $\$ 4,368$ made by the park cover $9.94 \%$ interest plus O\&M. The contract term is 10 years, with renewal option for an additional 5 years.

A utility company might also develop distributed generation projects to supply power for green power purchases. Green power refers to electric power generated from renewable energy resources, certified by a third party, and often sold at a premium price.

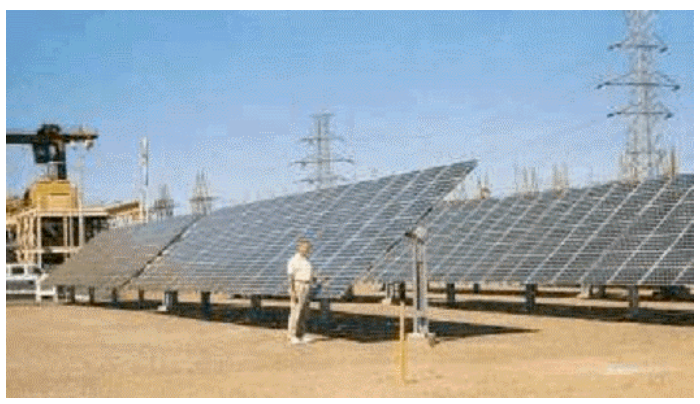

DG Financing Example 9: Green Power. Arizona Public Service "Solar Partners" installed $82 \mathrm{~kW}$ in Flagstaff. The cost was $\$ 750,000$ minus $2 / 3$ cost share. Customers participating in Solar Partners pay $\$ 2.64 /$ month per $100 \mathrm{~W}$, or $\$ 26,000 / y$. This corresponds to a $12 \%$ rate of return on program funds. The program was oversubscribed in 3 weeks, with $1 / 3$ surveyed willing to pay more for green power. The total amount of solar energy installed by the utility is nearly $1 \mathrm{MW}$. There are nearly 2,500 registered program participants [16].

\section{CHAUFFAGE}

Chauffage, from the French word for heat, is an arrangement under which a customer purchases the benefits of a distributed generation project (electricity, heating, or cooling) rather than financing and purchasing the hardware to achieve these benefits. This could be very appealing to a customer that does not wish to be burdened with development and ongoing operation of a distributed generation project. Risk of project non-performance falls totally on the owner/operator of the equipment. 


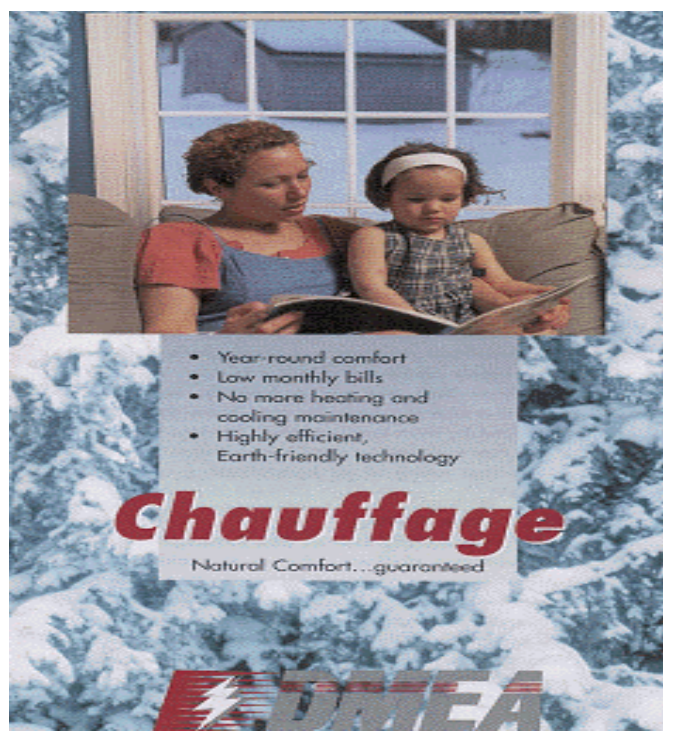

DG Financing Example 10: Chauffage. The Delta Montrose Electric Association finances installation and sells heating and cooling from ground-source heat pumps to customers. DMEA has installed one fuel cell at a residence $[15]$.

\section{GRANTS}

Grants are sometimes available from the government to promote new technologies or support government programs. In these cases, the government is promoting an objective that may be in alignment, with, but also may be tangential to, the objectives of the project participants. Government grants are often awarded through a competitive proposal process and often entail a lot of reporting requirements. Grants are also sometimes available from environmental or philanthropic organizations. Donations of equipment are sometimes available from suppliers. Grants or donations are usually sought by organizations that have a charitable mission or offer a rare opportunity to showcase a project to a large number of visitors. The pursuit of grants and donations is sometimes a twoedged sword, causing project delays and unfulfilled expectations ("Why should I finance it now if I might get a grant later?" But the grant never comes).

\section{VENTURE CAPITAL}

The discussion above describes alternatives for financing distributed generation projects, largely from the perspective of the end-use customer. In order to complete the discussion of financing, we turn attention now to financing businesses involved in distributed generation services.

Venture capitalists are organizations or individuals that invest in business ventures through equity, debt, or a combination of equity and debt. Venture capitalists invest in highgrowth opportunities (rather than seeking stable dividends) in order to achieve expected rates of return of $25 \%$ to $80 \%$ or higher [19]. Institutional investors would generally not consider investments of less than $\$ 250,000$. Venture capitalists look for intellectual property rights and market potential, both of which are very high right now for distributed generation. This may partially explain the explosive growth in this area; venture capital investment in distributed generation technologies has skyrocketed in recent years, from about $\$ 20$ million in 1995 to almost $\$ 800$ million in 2000 [5]. In addition to being a source of funds, venture capitalists bring business experience and professional contacts while usually requiring a say in the business through board participation.

\section{INFORMAL INVESTORS: "ANGELS"}

"Business angels" are wealthy individuals, often retired executives, who have funds to invest and perhaps an interest in a technical field. Informal investors buy shares in a company and have varying, but often less demanding, requirements for rate of return. Investments are ordinarily limited to less than $\$ 50,000$, but syndicates of business angels might offer up to $\$ 250,000$. Angel investors are an important source of "seed" capital, helping to fund ventures from idea to demonstration of commercial viability. While some venture capital firms invest in seed opportunities that have no proven product, angel investors remain the primary source of funding for entrepreneurs working in the earliest stages of a new technology or business concept. Unlike institutional investors, business angels are not good providers of follow-up financing for future expansion or implementation of the next phase of a business plan. There are no fees or lengthy application, but it is difficult to find angels willing to invest in an enterprise. Finally, business angels can become "business devils" if their technical interest in the business causes disagreements or struggles for control. 


\section{STOCK MARKET}

Initial public offerings (IPO) of publicly traded stock would be a likely way for a venture capitalist to exit and cash out her investment (acquisition by another company would be the other way). With no interest and no requirement to repay, the stock market is the Mecca of business financing. The loss of control of a company is usually proportional to the amount of equity that is sold to outside investors. The regulators do not control the company; they just administer rigorous entry requirements and accounting discipline to ensure that required reports are submitted in the right format. Regulators do not check the financial or technical viability of the company (for example, I could issue stock for Andy's Perpetual Motion Machine Company). Some states, however, do manage such controls (for example, I couldn't sell stock for a perpetual motion machine in Massachusetts, since it is understood there that such a machine is impossible).

A company works with a team of underwriters on the IPO. The underwriters perform several important functions in addition to coordinating the application and reporting required by regulators, such as determining the initial price. With only hours or days of information for investors to make decisions on, the initial performance of a stock is critical. If the price initially goes down, investors will assume it will continue the decline and the stock is said to "tank." If the price goes up, investors will continue to buy the stock until the price stabilizes at some acceptable value, and the stock is said to "float." Once a stock is floated on the market, volatility in the share price affects the company's ability to raise more capital. For this reason, the stock is usually issued initially at a value less than its expected value, in order to ensure that the initial performance is an increase in the price. Perhaps not coincidentally, this also improves the profit of the underwriters. In 2000, nearly $\$ 3$ trillion was invested in funds and portfolios that are screened for social responsibility, up 400\% from 1995 [6]. Distributed generation using cogeneration, solar, or other desirable environmental attributes may benefit from this trend.

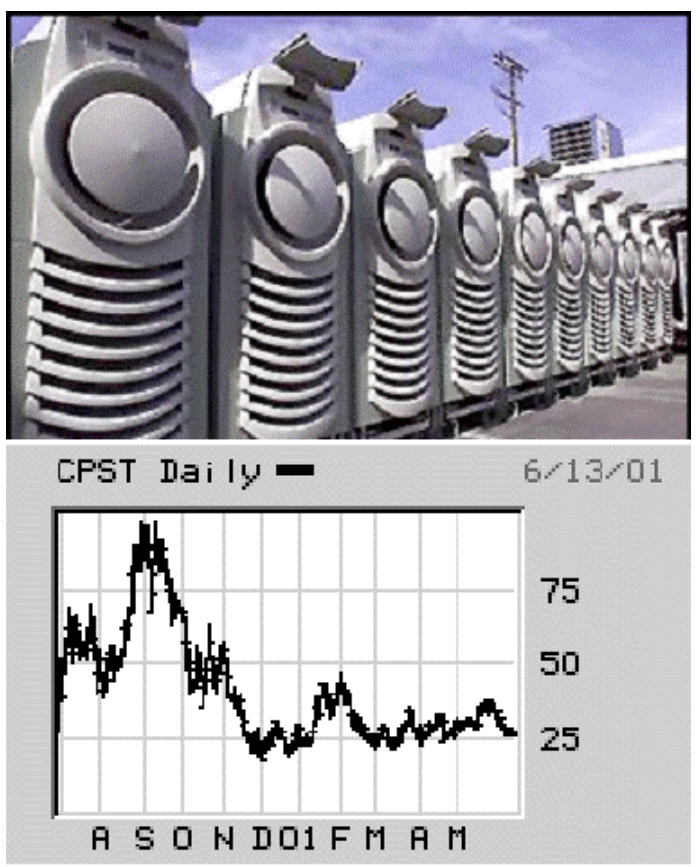

DG Financing Example 11: Stock Market. Capstone Turbine Corp. issued an IPO of common stock on NASDAQ June 29, 2000. Net proceeds were estimated at $\$ 133.3$ million. The underwriting team was Goldman, Sachs \& Co., Merrill Lynch \& Co., and Morgan Stanley Dean Witter; 9,090,909 shares issued. Notice how price stabilized near \$25/share, higher than the \$16/share issue price [14].

\section{REFERENCES}

[1] Discount Rate and Fuel Escalation Rates for Federal Life Cycle Cost Analysis. NISTIR 853273-16, updated annually, 2001.

[2] The Borrower's Guide to Financing Solar Energy Systems: A Federal Overview, $2^{\text {nd }}$ Edition DOE/GO-10099-742, March 1999. Available from NTIS (703) 487-4650.

[3] Sacramento Municipal Utility District Press Release on SMUD Solar Pioneers Program. www.smud.org accessed February 2001

[5] Capital-E website, cap-e.com, accessed February 2000.

[6] Seattle Times article by Andrew Melynovich. http://archives.seattletimes.nwsource.com/web/.

Accessed February 2001.

[7] Financing Energy Projects Deskbook. Albert Thurman Fred Wainwright ISBN 0-88173-272-9 The Fairmont Press Inc. 1997. 
[8] Financing Innovation Website http://www.cordis.lu/finance/src/acc-fin.htm.

Accessed January 2001.

[9] FEMP Project Facilitators' Workshop

May 23, 2000, Knoxville, Tennessee Bruce Gross and Scott Foster of GE Capital- Potomac Federal, Anita Molino of Bostonia Partners LLC, and Bob Brozey of ABB Energy Capital.

[10] Energy Information administration Renewable Energy Annual 1996, April 1997, http://www.eia.doe.gov/cneaf/solar.renewables/rene wable.energy.annual/chap05.html.

[11] Average for the state of California, 1999. from www.eia.doe.gov, accessed February 2001.

[12] Presentation prepared by Michael Fulton, PE York International Corporation, 2000.

[13] Department of Defense Fuel Cell

Demonstration Program

http://dodfuelcell.com/site performance.php3,

Accessed June 2001.

[14] Capstone Turbine Corp. website www.capstoneturbine.com Accessed June 2001.

[15] Chauffage Brochure. Delta Montrose Electric Association. www.dmea.com, Accessed March 2001.

[16] Department of Energy, Office of Energy Efficiency and Renewable Energy http://www.eren.doe.gov/greenpower/gp ious.html, Accessed June 2001.

[17] Interview with Ken May, Industrial Solar Technology Inc., Golden CO. February 2001.

[18] Interview with homeowner Dorothy (last name withheld), February 2001.

[19] Comments on draft paper provided by Marty Murphy and Christopher Boyle of NREL, June 26, 2001.

[20] Hours/year $=$ annual $\mathrm{kWh}$ produced $/$ installed capacity. Solar and wind resource from www.nrel.gov. Power output average of several turbine models from calculator at http:/www.windpower. dk/tour /wres/ pow/index.htm. Accessed July 26, 2001.

[21 Fundamentals of Municipal Bonds, $3^{\text {rd }}$ ed. Public Securities Association, 1987. 
Public reporting burden for this collection of information is estimated to average 1 hour per response, including the time for reviewing instructions, searching existing data sources,

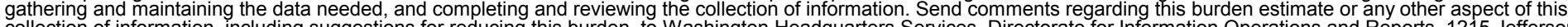
Davis Highway, Suite 1204, Arlington, VA 22202-4302, and to the Office of Management and Budget, Paperwork Reduction Project (0704-0188), Washington, DC 20503.
1. AGENCY USE ONLY (Leave blank)
2. REPORT DATE
August 2001
3. REPORT TYPE AND DATES COVERED Conference Paper

4. TITLE AND SUBTITLE

Financing Distributed Generation

6. $\mathrm{AUTHOR}(\mathrm{S})$

Andy Walker, PhD, PE

7. PERFORMING ORGANIZATION NAME(S) AND ADDRESS(ES)

National Renewable Energy Laboratory

1617 Cole Blvd.

Golden, CO 80401-3393

9. SPONSORING/MONITORING AGENCY NAME(S) AND ADDRESS(ES)
5. FUNDING NUMBERS

FE01.3052

8. PERFORMING ORGANIZATION

REPORT NUMBER

NREL/CP-710-30554

9. SPONSORING/MONITORING AGENCYNAME(S) AND ADDRESS(ES)

10. SPONSORING/MONITORING AGENCY REPORT NUMBER

11. SUPPLEMENTARY NOTES

12a. DISTRIBUTION/AVAILABILITY STATEMENT

National Technical Information Service

U.S. Department of Commerce

5285 Port Royal Road

Springfield, VA 22161

13. ABSTRACT (Maximum 200 words)

This paper introduces the engineer who is undertaking distributed generation projects to a wide range of financing options. Distributed generation systems (such as internal combustion engines, small gas turbines, fuel cells and photovoltaics) all require an initial investment, which is recovered over time through revenues or savings. An understanding of the cost of capital and financing structures helps the engineer develop realistic expectations and not be offended by the common requirements of financing organizations. This paper discusses several mechanisms for financing distributed generation projects: appropriations; debt (commercial bank loan); mortgage; home equity loan; limited partnership; vendor financing; general obligation bond; revenue bond; lease; Energy Savings Performance Contract; utility programs; chauffage (end-use purchase); and grants. The paper also discusses financial strategies for businesses focusing on distributed generation: venture capital; informal investors ("business angels"); bank and debt financing; and the stock market.

14. SUBJECT TERMS
distributed generation; financing; investment; savings; financing structures and options;
initial costs; strategies

17. SECURITY CLASSIFICATION OF REPORT Unclassified
18. SECURITY CLASSIFICATION OF THIS PAGE Unclassified
19. SECURITY CLASSIFICATION OF ABSTRACT Unclassified
15. NUMBER OF PAGES

16. PRICE CODE

20. LIMITATION OF ABSTRACT

UL 